\section{Aluminum Amendment of Potting Mixes for Control of Phytophthora Damping-off in Bedding Plants}

\author{
D.M. Benson \\ Department of Plant Pathology, North Carolina State University, Raleigh, \\ NC 27695-7629 \\ Additional index words. Phytophthora parasitica, exchangeable aluminum, Antirrhinum \\ majus, Catharanthus roseus, Petunia $\times$ hybrida, disease suppression
}

\begin{abstract}
Control of preemergence damping-off caused by Phytophthora parasitica Dastur was investigated on three bedding plant species in a 1 peat : 1 vermiculite medium $(\mathrm{v} / \mathrm{v})$ limed at $3 \mathrm{~kg} \cdot \mathrm{m}^{-3}$ and drenched with aluminum at 10,25 , or $50 \mathrm{meq} \mathrm{Al} / 100 \mathrm{~cm}^{3}$ medium. Aluminum as $\mathrm{Al}_{2}\left(\mathrm{SO}_{4}\right)_{3}$ was applied as a drench at $0.75,1.9$, or $3.75 \mathrm{~g} / 150 \mathrm{ml}$ water to the surface of infested medium in $650-\mathrm{cm}^{2}$ plug trays $\left(1300-\mathrm{cm}^{3}\right.$ tray volume $)$. All concentrations of aluminum were effective in controlling preemergence damping-off of snapdragon (Antirrhinum majus L.) and vinca (Catharanthus roseus G. Don, Madagascar periwinkle), but only 50 meq $\mathrm{Al}^{+3} / 100 \mathrm{~cm}^{3}$ medium was effective for petunia (Petunia $\times$ hybrida Hort. Vilm.-Andr.). At 4 days after seeding and drenching with aluminum sulfate, exchangeable aluminum was $0,0.5$, and 2.03 meq $\mathrm{Al}^{+3} / 100 \mathrm{~g}$ medium, respectively, for the three concentrations used. Control of damping-off of snapdragon and vinca with 10 meq $\mathrm{Al}^{+3}$ / $100 \mathrm{~cm}^{3}$ medium with no detectable exchangeable aluminum 4 days after application suggests that $P$. parasitica was suppressed by aluminum early in the host-pathogen interaction, whereas petunia was susceptible to damping-off for a longer period before seedling emergence. Aluminum was not phytotoxic to vinca, snapdragon, or petunia grown in a limed medium.
\end{abstract}

Damping-off caused by Phytophthora parasitica Dastur, Pythium spp., and Rhizoctonia solani Kuhn is an important disease problem of bedding plants for many growers. Traditionally, damping-off has been controlled by the use of soilless mixes, sanitation, manipulation of the environment, and fungicides that suppress development of damping-off pathogens. In previous studies, Thielaviopsis basicola (Berk. \& Broome) Ferraris, cause of black root rot of burley tobacco (Meyer and Shew, 1991), and P. parasitica Breda de Haan var. nicotianae (Dastur) G.M. Waterhouse, cause of black shank of tobacco (Deluca and Shew, 1988), were suppressed by aluminum. Recently, Benson (1993a) demonstrated that drenches of aluminum sulfate to a peat : vermiculite medium controlled preemergence damping-off of $C$. roseus caused by $P$. parasitica. In a nonlimed peat : vermiculite

Received for publication 22 Nov. 1994. Accepted for publication 21 July 1995 . This research was supported by the North Carolina Agricultural Research Service, North Carolina State Univ., Raleigh. I thank Billy I. Daughtry for his technical assistance. This publication reports research involving an antimicrobial substance. It does not contain recommendations for its use, nor does it imply that the uses discussed here have been registered. All uses of pesticides must be registered by appropriate state and federal agencies before they can be recommended. The cost of publishing this paper was defrayed in part by the payment of page charges. Under postal regulations, this paper therefore must be hereby marked advertisement solely to indicate this fact. medium at $\mathrm{pH} 4.4$, as little as 17 meq of $\mathrm{Al} / 100$ $\mathrm{cm}^{3}$ medium controlled damping-off; however, when the medium was limed to $\mathrm{pH} 5.8$, as much as 100 meq of $\mathrm{Al} / 100 \mathrm{~cm}^{3}$ medium was needed for disease control (Benson, 1993a). Differences in amount of aluminum needed for control at $\mathrm{pH}$ values appropriate for bedding plant production was correlated with exchangeable aluminum in the medium. In general, as the $\mathrm{pH}$ of a medium increases the amount of exchangeable aluminum $\left(\mathrm{Al}^{+3}\right)$ decreases, such that there is very little exchangeable trivalent aluminum at $\mathrm{pH} 6$ (Tisdale et al., 1985).

The objective of this research was to determine the rate of aluminum needed to control preemergence damping-off caused by $P$. parasitica on three bedding plant species in a soilless medium limed for adequate plant growth.

\section{Materials and Methods}

The soilless medium used was a 1 peat : 1 vermiculite $(\mathrm{v} / \mathrm{v})$ mixture with an initial $\mathrm{pH}$ of 4.1 in $1: 2 \mathrm{CaCl}_{2}$. The peat had been screened through a $6-\mathrm{mm}$ screen to remove large stem and root fragments. As the peat and vermiculite were mixed in a cement mixer, dolomitic limestone at the rate of $3 \mathrm{~kg} / \mathrm{m}^{3}$ medium was incorporated. The prepared medium was used to fill 81-cell plug trays $(25.4 \times 25.4 \times 2.54 \mathrm{~cm}$, i.e., standard 162-cell trays cut in half). The trays were then placed on a greenhouse bench and misted for 2-min intervals five times a day. This rate of misting kept the medium moist but not completely saturated. Trays were main- tained under the mist system for 3 days to allow partial equilibration of the lime in the medium. After the equilibration period, the trays were seeded with 'Little Bright Eyes' vinca (69\% germination), 'Tetra Ruffled Supreme Mix' snapdragon (55\% germination), or with 'Supercascade White' petunia (86\% germination) by use of a custom 81-cell vacuum seeder (Berry Seeder Co., Elizabeth City, N.C.).

Twice-autoclaved rice grains ( $25 \mathrm{~g}$ rice/ 19 $\mathrm{ml}$ deionized water) in 125-ml Erlenmeyer flasks were seeded with two to three 7-mmdiameter potato dextrose agar disks of isolate 336 of $P$. parasitica (Holmes and Benson, 1994). Flasks were incubated on the laboratory bench at ambient temperature without supplementary light. Flasks were shaken occasionally to prevent clumping of grains. After 30 to 40 days of growth, the rice grains were pulverized in a blender for 1 to $2 \mathrm{~min}$, then screened through a sieve with 2-mm openings to select particles of uniform size. Pulverized rice grains $(0.05 \mathrm{~g})$ were mixed with $150 \mathrm{~cm}^{3}$ peat: vermiculite medium for vinca or $100 \mathrm{~cm}^{3}$ for petunia and snapdragon in a $850-\mathrm{ml}$ plastic bottle. Moist peat : vermiculite medium had been reserved in shaded plastic bags on the greenhouse bench during the 3-day equilibration period. After mixing, the infested medium was sprinkled, through $1-\mathrm{cm}$ holes in the lid, onto the surface of the seeded $650-\mathrm{cm}^{2}$ trays $\left(1300 \mathrm{~cm}^{3}\right.$ of medium/tray). Medium without colonized rice grains was used to cover seeds in the control treatment. The trays were then misted twice for $2 \mathrm{~min}$ to settle the covering medium.

After misting, aluminum at $0,10,25$, or 50 meq $\mathrm{Al} / 100 \mathrm{~cm}^{3}$ medium $(0,10,25,50 \mathrm{Al})$ was drenched to the surface of plug trays by dissolving the appropriate amount of aluminum sulfate $\left[\mathrm{Al}_{2}\left(\mathrm{SO}_{4}\right)_{3}\right]-0,0.75,1.9$, or $3.75 \mathrm{~g}$, respectively - in $150 \mathrm{ml}$ of water. Each solution was placed in a $850-\mathrm{ml}$ plastic bottle and applied evenly to the surface of the $650-\mathrm{cm}^{2}$ plug trays through $0.8-\mathrm{mm}$ holes in the lid. The rates of aluminum chosen were based on control of phytophthora damping-off of vinca over a $\mathrm{pH}$ range of 4.1 to 6 in previous experiments (Benson, 1993a).

Plug trays were arranged by treatment in a randomized complete-block design with four replications. Trays were maintained under the mist system during germination and emergence. After 16 days for vinca, and 19 days for petunia and snapdragon, trays were transferred to a capillary-mat watering system on a greenhouse bench. Stand counts were taken at emergence and at $\approx 2$-day intervals thereafter, until tests were complete. At 18 and 32 days after seeding, six randomly selected seedlings in each tray were measured for plant width in the case of petunia and snapdragon, or for length of the first true leaf for vinca to assess aluminum phytotoxicity.

Four days after seeding, samples of potting medium were removed at random from each replication and composited by treatment for determination of $\mathrm{pH}$ and exchangeable aluminum. Medium $\mathrm{pH}$ was determined in $1: 2 \mathrm{CaCl}_{2}$ (Smiley and Cook, 1972). Exchangeable aluminum, expressed as milliequivalents of $\mathrm{Al}^{+3}$ / 


\section{Plant Pathology}

$100 \mathrm{~g}$ medium, was determined by $1 \mathrm{~N} \mathrm{KCl}$ extraction of medium samples with a baseacid titration method that involved sodium fluoride (Yuan, 1959).

Forty-two days after seeding, six plugs for each plant species were selected at random from each plug tray and transplanted into a 82$\mathrm{cm}^{3}$, six-cell market pack of peat : vermiculite medium at $\mathrm{pH}$ 4.7. Immediately after transplanting, the corresponding rate of aluminum from the initial treatment was applied in $75 \mathrm{ml}$ of water to the surface of the medium, as described above. Plants were fertilized weekly with 100 ppm N (20:20:20; Peters, Allentown, $\mathrm{Pa}$.). At 45 and 60 days after seeding, plant height for the six seedlings in each market pack was measured.

Stand counts among treatments, plant widths, leaf length, and plant height measurements were compared by analysis of variance (ANOVA) with the PROC ANOVA procedure of PC SAS (SAS Institute, Cary, N.C.). Mean separation was by Waller-Duncan $\mathrm{k}$ ratio $t$ test, $\mathrm{k}=100, P=0.05$. Experiments were repeated three times and representative data from one experiment presented.

\section{Results}

Vinca. Stand counts of vinca seedlings were lower $(P=0.05)$ in the infested, nontreated control due to preemergence damping-off caused by $P$. parasitica compared to the noninfested control (ck) at 11 days after seeding (Fig. 1). Based on stand count in the noninfested control, preemergence dampingoff caused by $P$. parasitica was $56.2 \%$ in the infested control. When drenches of aluminum at rates of 10 to $50 \mathrm{Al}$ were applied to infested medium seeded with vinca, stand counts were different $(P \leq 0.05)$ from the infested, nontreated control but the same as counts in the noninfested control(Fig. 1). Preemergence damping-off was $9.5 \%, 0 \%$, and $0 \%$ for 10,25 , and $50 \mathrm{Al}$, respectively, based on stand count for the noninfested control.

Snapdragons. No damping-off of snapdragons occurred in medium amended with 25 or $50 \mathrm{Al}$, respectively, and stand counts were not different $(P>0.05)$ from the noninfested control (Fig. 1). Preemergence damping-off in snapdragons not drenched with aluminum averaged $48 \%$ in the infested control with $P$. parasitica. At $10 \mathrm{Al}$, damping-off was $21 \%$, but stand count was not different $(P>0.05)$ from the noninfested control (Fig. 1).

Petunia. In petunia, 10 and $25 \mathrm{Al}$ did not control preemergence damping-off ( $29 \%$ and $20 \%$ diseased plants, respectively), compared to the infested control $(0 \mathrm{meq})$ and stand counts were similar to that of the noninfested control (Fig. 1). Damping-off in petunia was $58 \%$ in the infested control without aluminum amendment. At $50 \mathrm{Al}$, damping-off of petunia averaged only $2.4 \%$ and stand count was greater than $(P \leq 0.05)$ the infested control (Fig. 1).

$p H$. Medium $\mathrm{pH}$ ranged from 5.5 to 5.6 in composite samples from treatments without aluminum amendment 4 days after seeding (Fig. 2). As the rate of aluminum amendment increased from 10 to $50 \mathrm{Al}$, medium $\mathrm{pH}$

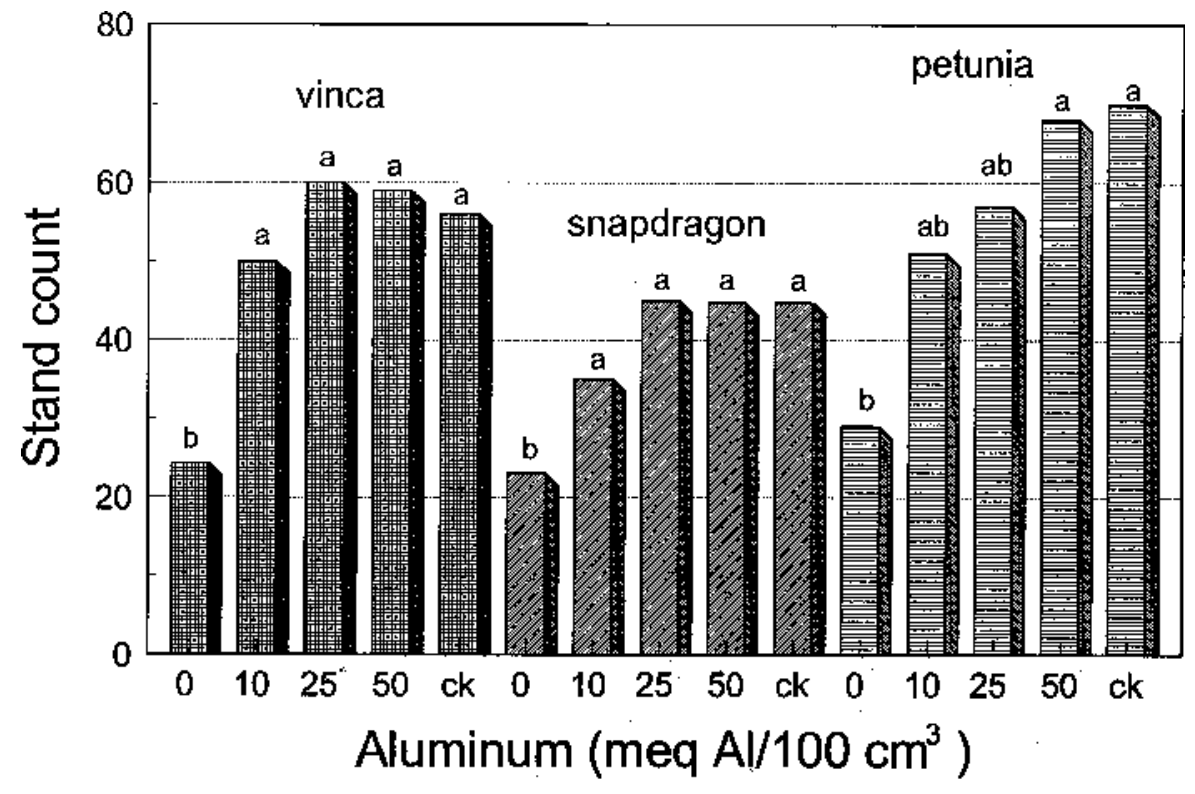

Fig. 1. Stand counts for vinca, snapdragon, and petunia grown in a peat : vermiculite medium limed at 3 $\mathrm{kg} \cdot \mathrm{m}^{-3}$ and infested with Phytophthora parasitica. The medium was drenched with aluminum sulfate at $0,10,25$, or $50 \mathrm{meq} \mathrm{Al}{ }^{+3} / 100 \mathrm{~cm}^{3}$ medium. The control designated "ck" was neither infested nor drenched with aluminum. Mean separation within species (means of four replications) by the WallerDuncan k ratio $t$ test, $\mathrm{k}=100, P=0.05$.

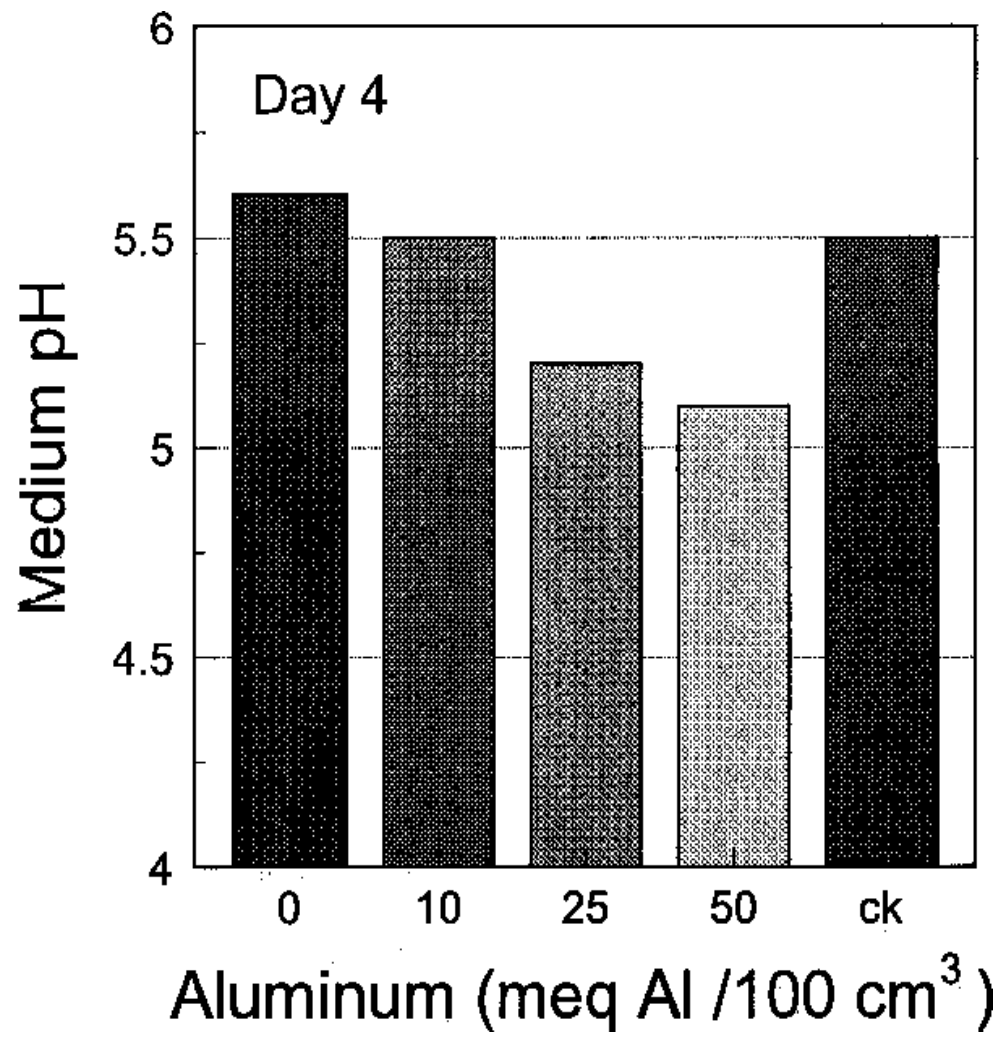

Fig. 2. Medium $\mathrm{pH}$ at 4 days after seeding and drenching a limed peat : vermiculite medium with aluminum sulfate at $0,10,25$, or 50 meq $\mathrm{Al}^{+3} / 100 \mathrm{~cm}^{3}$ medium. Samples were taken at random from plug trays of vinca, snapdragon, and petunia infested with Phytophthora parasitica. The control designated "ck" was neither infested nor drenched with aluminum.

dropped from 5.5 to 5.1 , respectively, 4 days after seeding (Fig. 2).

Exchangeable aluminum. Four days after seeding, exchangeable aluminum from composite samples across crop species was 0 and $0.13 \mathrm{meq} / 100 \mathrm{~g}$ medium in the infested control (0 meq) and noninfested control (ck), respec- tively (Fig. 3). No exchangeable aluminum was detected in samples from medium drenched at $10 \mathrm{Al}$. Exchangeable aluminum was 0.5 and $2.03 \mathrm{meq} / 100 \mathrm{~g}$ medium in samples from media drenched with 25 and $50 \mathrm{Al}$, respectively, at 4 days.

Plant growth. Eighteen days after seeding, 
lengths of the first true leaves of vinca were similar $(P>0.05)$ among treatments (range 8.6 to $9.7 \mathrm{~mm})$. At day 32 , however, first true leaves in the infested control were $\operatorname{shorter}(P=$ $0.0001)$ than in treatments with aluminum or the noninfested control (Table 1). Heights of vinca seedlings at day 45 (range 47 to $68 \mathrm{~mm}$ ) and day 60 (range 101 to $159 \mathrm{~mm}$ ) after seeding were similar $(P>0.05)$ among treatments.

At day 45, snapdragon seedlings in the infested control and in medium amended with $50 \mathrm{Al}$ were shorter $(P=0.036)$ than seedlings in medium amended with $25 \mathrm{Al}$ (Table 1). At day 60, no differences in height of snapdragon seedlings (range 148 to $235 \mathrm{~mm}$ ) were detected among treatments. Plant width at day 18 and day 32 (range 33 to $42 \mathrm{~mm}$ ) after seeding was similar for all treatments.

At 32 days after seeding, petunia seedlings in the noninfested control and medium drenched with $25 \mathrm{Al}$ were larger $(P \leq 0.005)$ than seedlings in other treatments (Table 1). No differences in heights of petunia seedlings were detected at 45 and 60 days (range 202 to $255 \mathrm{~mm}$ ).

\section{Discussion}

Drenches of aluminum to a peat : vermiculite medium at 10 to $50 \mathrm{Al}$ were effective in controlling preemergence damping-off, but differences existed among bedding plants tested. Damping-off of vinca and snapdragon was controlled at all rates of aluminum tested, whereas only the $50 \mathrm{Al}$ treatment completely controlled damping-off of petunia.

Previous research with $P$. parasitica has shown a close correlation between exchangeable aluminum at 4 days after seeding vinca and subsequent development of preemergence damping-off(Benson, 1993a). Apparently, the first few days after seeding are critical in emergence of healthy seedlings or development of disease even though seedlings may not actually emerge until several days later. Thus, it appears for vinca and snapdragon, where control of preemergence damping-off was good at a rate as low as $10 \mathrm{Al}$, that the critical interaction of exchangeable aluminum with pathogen suppression occurs within 4 days. In addition, the amount of exchangeable aluminum must have been very low during this period, since exchangeable aluminum was not detectable at 4 days after seeding when applied at $10 \mathrm{Al}$. The transitory nature of exchangeable aluminum when applied at low rates to a peat : vermiculite medium limed at $3 \mathrm{~kg} \cdot \mathrm{m}^{-3}$ suggests that long-term disease control would not be effective if the crop were susceptible to $P$. parasitica at other stages of growth. This situation would apply for the phytophthora blight disease that develops on foliage of vinca as a result of splash dispersal of inoculum to foliage of seedlings or even flowering plants in the landscape (Benson, 1993b).

However, for petunia, only $50 \mathrm{Al}$ of aluminum was effective in disease control where exchangeable aluminum was $2.03 \mathrm{meq} \mathrm{Al}^{+3}$ / $100 \mathrm{~g}$ medium at day 4 , suggesting that germinating petunia seed were susceptible to $P$. parasitica for a longer period than snapdragon

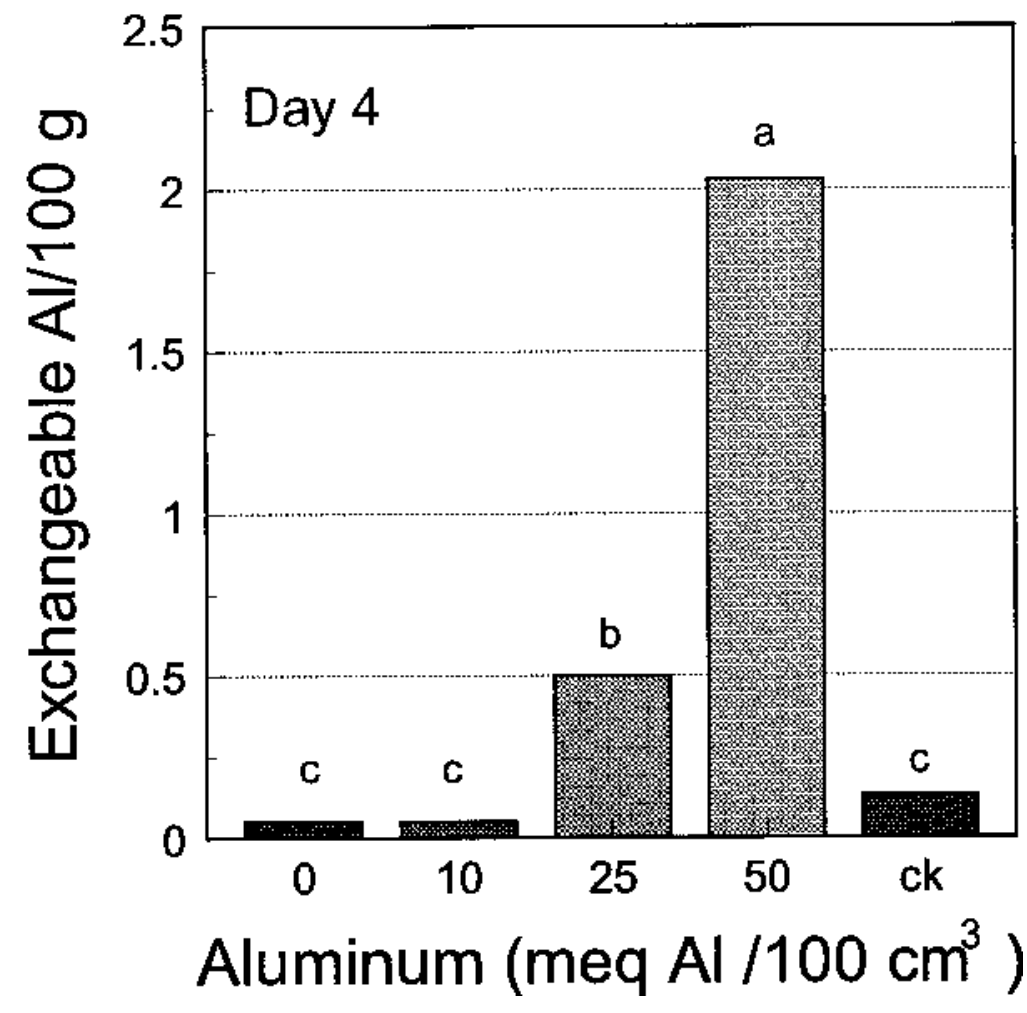

Fig. 3. Exchangeable aluminum (meq $\mathrm{Al}^{+3} / 100 \mathrm{~g}$ medium) at 4 days after seeding and drenching a limed peat : vermiculite medium with aluminum sulfate at rates of $0,10,25$, or 50 meq Al ${ }^{+3} / 100 \mathrm{~cm}^{3}$ medium. Samples were taken at random from plug trays of vinca, snapdragon, and petunia infested with Phytophthora parasitica. The control designated "ck" was neither infested nor drenched with aluminum. Mean separation (means of two replications) by the Waller-Duncan $\mathrm{k}$ ratio $t$ test, $\mathrm{k}=100, P=0.05$.

Table 1. Growth of bedding plant seedlings in peat : vermiculite medium infested or noninfested with Phytophthora parasitica and drenched with aluminum sulfate at 0 (noninfested and infested controls), 10,25 , or 50 meq $\mathrm{Al}^{+3} / 100 \mathrm{~cm}^{3}$ medium. ${ }^{2}$

\begin{tabular}{|c|c|c|c|}
\hline Al sulfate & Vinca $^{y}$ & Snapdragon $^{\mathrm{x}}$ & Petunia $^{w}$ \\
\hline$\left(\mathrm{meq} / 100 \mathrm{~cm}^{3}\right)$ & $\overline{\text { Length (mm) }}$ & $\overline{\mathrm{Ht}(\mathrm{mm})}$ & $\overline{\text { Width (mm) }}$ \\
\hline 0, noninfested & $24.6 \mathrm{a}$ & $97 \mathrm{ab}$ & $44 \mathrm{a}$ \\
\hline 0, infested & $16.3 \mathrm{~b}$ & $77 \mathrm{~b}$ & $38 \mathrm{~b}$ \\
\hline 10, infested & $22.8 \mathrm{a}$ & $99 \mathrm{ab}$ & $35 \mathrm{~b}$ \\
\hline 25 , infested & $24.6 \mathrm{a}$ & $116 \mathrm{a}$ & $44 \mathrm{a}$ \\
\hline 50, infested & $24.7 \mathrm{a}$ & $82 \mathrm{~b}$ & $35 \mathrm{~b}$ \\
\hline$P>\mathrm{F}$ & 0.0001 & 0.0356 & 0.0048 \\
\hline
\end{tabular}

${ }^{\mathrm{z}}$ Mean separation within a column by the Waller-Duncan $\mathrm{k}$ ratio $t$ test; $\mathrm{k}=100, P=0.05$.

${ }^{y}$ First true-leaf length measured at 32 days for vinca seedlings in plug trays.

xPlant height measured at day 45 for snapdragon seedlings retreated with aluminum at transplanting 42 days after seeding.

wPlant width measured at day 32 for petunia seedlings in plug trays.

and vinca before emergence. Therefore, exchangeable aluminum must remain at levels inhibitory to $P$. parasitica for longer periods.

In acidic soils with a $\mathrm{pH}$ near 4 , aluminum toxicity to plant growth can be a problem. In peat media with a naturally low $\mathrm{pH}$, potential aluminum toxicity can be corrected by adding lime. However, the natural suppressiveness of nonlimed peat media to sensitive soilborne pathogens due to high exchangeable aluminum is lost by liming. Amendment of peat media with aluminum in the form of aluminum sulfate may be one way to restore suppression to sensitive soilborne pathogens.

Vinca, snapdragon, and petunia seedlings were not sensitive to aluminum toxicity at rates of 10,25 , or $50 \mathrm{Al}$ when the peat : vermiculite medium was limed at $3 \mathrm{~kg} \cdot \mathrm{m}^{-3}$.
However, Benson (1993b) found that both petunia and snapdragon emerged poorly, and had restricted root systems and top growth when exposed to aluminum at $100 \mathrm{Al}$ in a nonlimed peat : vermiculite medium at $\mathrm{pH} 4.2$. Although only a limited number of bedding plant crops have been tested for aluminum tolerance (Benson, 1993b), it is apparent that even aluminum-sensitive crops such as petunia and snapdragon can be grown at favorable $\mathrm{pH}$ in environments with enough exchangeable aluminum to control damping-off due to $P$. parasitica. In practice, growers could use aluminum amendments to create levels of exchangeable aluminum in peat-based media that were suppressive to sensitive pathogens such as $P$. parasitica yet avoid aluminum phytotoxicity problems by liming the medium. 


\section{Plant Pathology}

\section{Literature Cited}

Benson, D.M. 1993a. Suppression of Phytophthora parasitica on Catharanthus roseus with aluminum. Phytopathology 83:1303-1308.

Benson, D.M. 1993b. Exchangeable aluminum in potting mixes: Effect on control of phytophthora damping-off and growth of bedding plants. Bedding Plants Foundation, East Lansing, Mich. no. F-052.
Deluca, T.H. and H.D. Shew. 1988. Inhibition of growth and reproduction of Phytophthora parasitica var. nicotianae by aluminum. Phytopathology 78:1576.

Holmes, K.A. and D.M. Benson. 1994. Evaluation of Phytophthora parasitica var. nicotianae for biocontrol of Phytophthora parasitica on Catharanthus roseus. Plant Dis. 78:193-199.

Meyer, J.R. and H.D. Shew. 1991. Soils suppressive to black root rot of burley tobacco, caused by Thiel- aviopsis basicola. Phytopathology 81:946-954.

Smiley, R.W. and R.J. Cook. 1972. Use and abuse of the soil $\mathrm{pH}$ measurement. Phytopathology 62:193-194.

Tisdale, S.L., W.L. Nelson, and J.D. Beaton. 1985. Soil fertility and fertilizers. 4th ed. Macmillan, New York.

Yuan, T.L. 1959. Determination of exchangeable hydrogen in soils by a titration method. Soil Sci. 88:164-167. 